\title{
MANAJEMEN ASET JARINGAN DISTRIBUSI ENERGI LISTRIK: SEBUAH PENDEKATAN SISTEM DINAMIK
}

\author{
Philip F.E. Adipraja, Erma Suryani, Rully A. Hendrawan \\ Jurusan Sistem Informasi, Fakultas Teknologi Informasi, Institut Teknologi Sepuluh Nopember \\ Kampus Keputih, Sukolio Surabaya 60111 \\ Telp: (031) 5999944, Fax: (031) 5964965 \\ E-mail: philipfaster@gmail.com
}

\begin{abstract}
Annual losses in the distribution of electrical energy is one of the obstacles for power companies such as PT. PLN. To reduce losses, need efforts to improve the network reliability through asset management. The asset management needs a simulation for long-term predictions. Simulation shows prediction of the funding impact to asset management strategy of electrical energy distribution network. This study used Dynamic Systems as simulation method. The study shows that the average of technical losses on PLN Pamekasan (2005-2013) is about 18,747,904 kWh / year. The simulation shows that low voltage network assets condition decreased by $1.71 \%$ per year, while the transformer assets conditions decreased by $2.02 \%$ per year, and the medium voltage network assets condition decreased by $1.65 \%$ per year.

\section{Abstrak}

Susut pada distribusi energi listrik setiap tahunnya merupakan salah satu kendala bagi perusahaan listrik seperti PT. PLN. Untuk mengurangi susut, perlu adanya usaha untuk meningkatkan keandalan jaringan melalui manajemen aset. Dalam manajemen aset dibutuhkan sebuah model simulasi untuk prediksi jangka panjang. Simulasi dapat menampilkan serta memprediksi dampak dari pendanaan terhadap strategi manajemen aset jaringan distribusi energi listrik. Dalam studi ini metode simulasi yang digunakan yaitu Sistem Dinamik. Hasil studi menunjukkan bahwa rata-rata susut teknis yang dialami PLN Pamekasan pada tahun 2005-2013 sebesar $18.747 .904 \mathrm{KWh} /$ Tahun. Hasil simulasi pada aset jaringan tegangan rendah mengalami penurunan kondisi sebesar 1,71\% per tahun, dimana pada aset transformer mengalami penurunan kondisi sebesar $2.02 \%$ per tahun, dan pada aset jaringan tegangan menengah mengalami penurunan kondisi sebesar 1,65\% pertahun.
\end{abstract}

Kata kunci: manajemen aset, jaringan distribusi, sistem dinamik, susut energi listrik

\section{PENDAHULUAN}

Energi yang ditransfer melalui jaringan distribusi listrik menghasilkan kerugian yang disebut Susut Energi Listrik (OFGEM, 2003). Jumlah susut ini semakin tinggi seiring dengan panjang saluran distribusi. Faktor-faktor yang berpengaruh terhadap susut distribusi diantaranya yaitu: konfigurasi jaringan, tingkat utilisasi, profil beban, dan faktor daya (power factor) (Top Energy, 2008). Manajemen aset jaringan dibutuhkan dalam usaha untuk meningkatkan keandalan jaringan yang secara tidak langsung akan mengurangi susut energi listrik.

Manajemen aset jaringan membantu dalam pembuatan keputusan untuk keberhasilan ekonomi jangka panjang dan pendapatan yang optimal bagi PLN. Dalam penelitian ini perawatan aset dapat dilakukan berdasarkan skala prioritas dengan mempertimbangkan kondisi dan risiko aset yang mana merupakan "Reliability Centered Maintenance". Perawatan
RCM sangat cocok untuk jaringan distribusi PLN Pamekasan sehingga dapat difokuskan berdasarkan skala prioritas pada aset yang mengakibatkan kerugian.

Adapun tujuan dari penelitian ini adalah untuk mengembangkan model sistem dinamik yang dapat memodelkan kondisi aset saat ini dan dapat digunakan untuk membantu memutuskan kebijakan manajemen aset yang yang dapat meminimalisir dampak dari terjadinya gangguan dan mengurangi penyusutan energi listrik. Aset jaringan distribusi pada PLN Pamekasan dapat menjadi dua kelompok berdasarkan jenis tegangannya yaitu Sambungan Tenaga Listrik Tegangan Rendah (SLTR) dan Sambungan Tenaga Listrik Tegangan Menengah (SLTM) (PT. PLN (Persero), 2010). Aset jaringan distribusi mencakup saluran udara, trafo daya, kabel tegangan menengah dan tegangan rendah yang sebagian besar terpasang di luar ruangan yang memiliki umur ekonomis sekitar 25 tahun. Apabila telah melampaui umur ekonomis, frekuensi 
rusak menjadi tinggi, yang dapat menyebabkan gangguan pasokan listrik pada pelanggan. Secara teknis, manajemen aset memerlukan sebuah model simulasi untuk prediksi jangka panjang. Simulasi dalam manajemen aset merupakan sebuah pendekatan untuk memprediksi dampak pendanaan pada strategi perawatan dan pembaharuan aset jaringan energi listrik (Gaul, Spitzer, \& Nilges, 2004).

Sistem dinamik berfokus pada hubungan timbal balik yang non linear dengan menimbang perubahan proses yang terjadi sepanjang horizon waktu perencanaan, sehingga memungkinkan pengguna untuk memodelkan sistem yang sangat kompleks (Wenzler \& Ivo, 2005). Metode Sistem Dinamik ini mempermudah pembuatan dan analisis skenario dan penilaian terhadap aset jaringan. Dengan kata lain, pendekatan sistem dinamik dapat mempertimbangkan faktor internal maupun eksternal yang bersifat non linear yang sulit dipecahkan dengan pendekatan matematis. Selain itu dengan sistem dinamik memungkinkan untuk mengembangkan skenario yang dapat memproyeksikan kemungkinankemungkinan yang akan terjadi di masa depan, sehingga sangat cocok diterapkan pada manajemen aset jaringan distribusi energi listrik.

\section{METODOLOGI}

Sistem dinamik merupakan pendekatan dengan bantuan komputer untuk menganalisa dan mendesain suatu kebijakan. Secara harfiah setiap sistem dinamik ditandai dengan ketergantungan, interaksi mutualisme, umpan balik informasi, dan perputaran sebab akibat (Richardson, 2013).

Pendekatan sistem dinamik dimulai dari penentuan masalah dari waktu ke waktu, dilanjutkan dengan tahap pemetaan dan pemodelan variabel-variabel yang memiliki pengaruh dalam model. Setelah variabel-variabel dianggap cukup dan sesuai tujuan, selanjutnya yaitu tahap pengembangan stock and flow diagram yang prosesnya yaitu mengidentifikasi arus masuk atau akumulasi (level) dalam sistem dan arus keluar (rate). Dilanjutkan dengan pengembangan model dan disimulasikan dengan bantuan komputer. Tahap terakhir yaitu menerapkan perubahan yang dihasilkan dari pemahaman dan pandangan berdasarkan model yang telah dihasilkan (Richardson, 2013).

Dalam proses simulasi langkah-langkah pengerjaan yang diadopsi dari Sterman yaitu diawali dengan penentuan masalah dan pengembangan model (Sterman, 2000). Setelah itu model divalidasi dengan dua cara yaitu perbadingan rata-rata (Mean Comparison) dan perbandingan variasi amplitudo (Variance
Comparison) (Barlas, 1996). Setelah model divalidasi, dilanjutkan dengan pembuatan skenario untuk memperbaiki kinerja sistem sesuai dengan tujuan. Proses terakhir yaitu penarikan kesimpulan dari hasil output model simulasi dan penerapan model pada sistem.

\section{HASIL DAN PEMBAHASAN}

Untuk membangun sistem dinamik akan dilakukan beberapa tahapan diantaranya yaitu pengembangan model sistem dinamik, proses simulasi dan penyusunan skenario.

\subsection{Pengembangan Model Sistem Dinamik}

Aset PLN membutuhkan modal dan siklus biaya yang tinggi dimana aset tersebut memiliki umur relatif panjang yang perlu dikelola secara efektif untuk mendapatkan manfaat sebesar-besarnya. Penurunan kondisi aset dari waktu ke waktu secara tidak langsung akan menyebabkan peningkatan biaya perawatan, menimbulkan masalah pada manajemen resiko lainnya, dan berdampak pada lingkungan, ekonomi dan biaya operasional (DIER, 2005). Manajemen aset dilakukan untuk mendukung tercapainya sasaran dan target kinerja. Target kinerja jaringan menjadi dasar dalam perencanaan dan perawatan aset berkala. Hal tersebut juga menjadi dasar dalam menentuan keputusan penggantian dan perawatan aset. Dengan tercapainya target yang diharapkan layanan pada pelanggan akan meningkat. Keterkaitan tersebut terlihat pada Gambar 1. Kinerja jaringan dipengaruhi oleh beberapa faktor, yaitu temperatur, kelembaban, cuaca, geografis, dan faktor beban (Crisp, 2004), seperti terlihat pada Gambar 2.

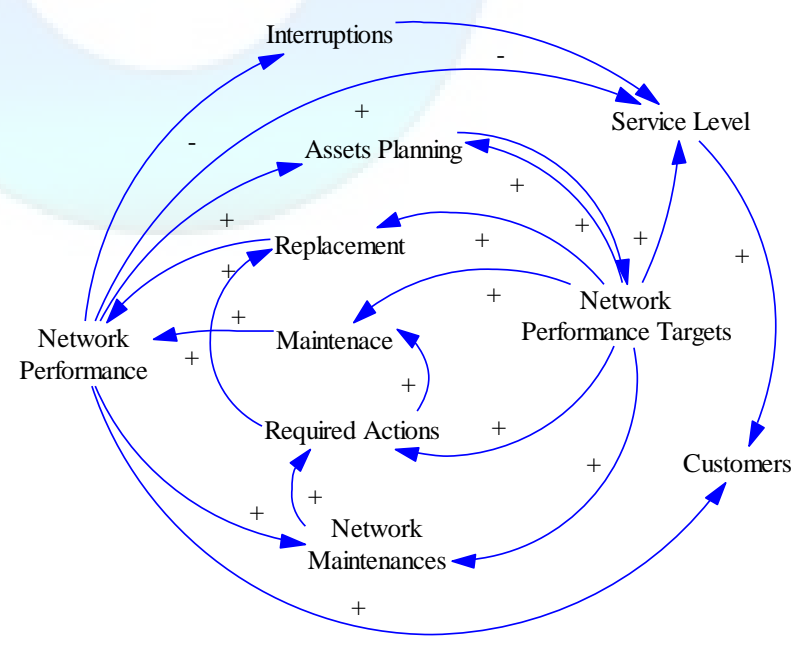

Gambar 1. Keterkaitan target kinerja, perawatan, dan tingkat layanan (PT. PLN Persero, 2012). 


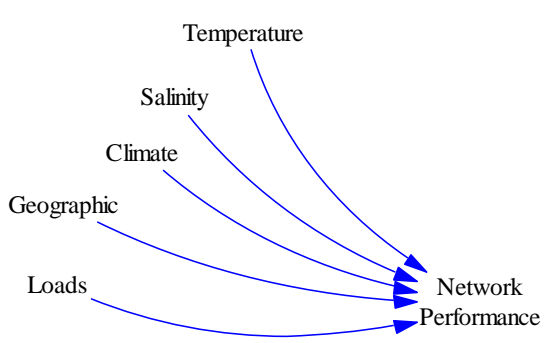

Gambar 2. Variabel signifikan terhadap kinerja aset jaringan (Crisp, 2004)

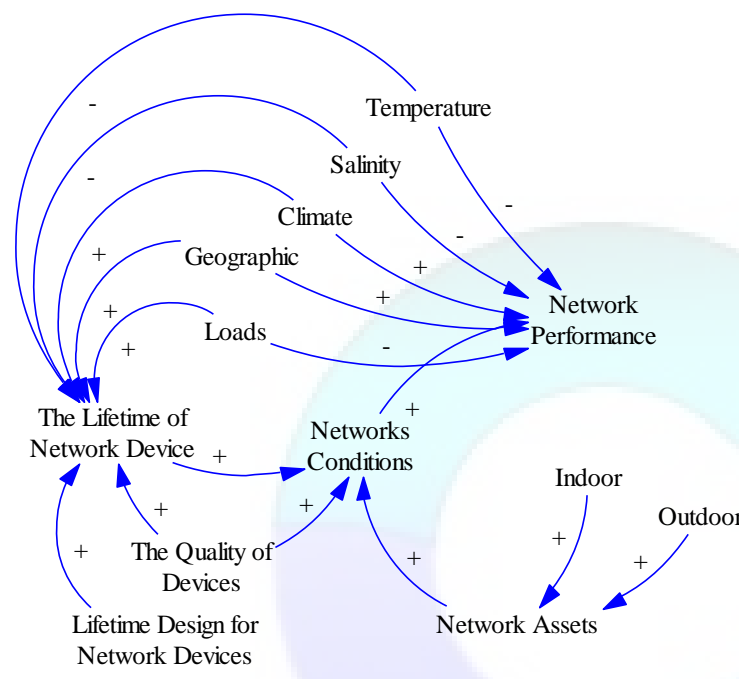

Gambar 3. Keterkaitan variabel desain usia aset (Crisp, 2004)

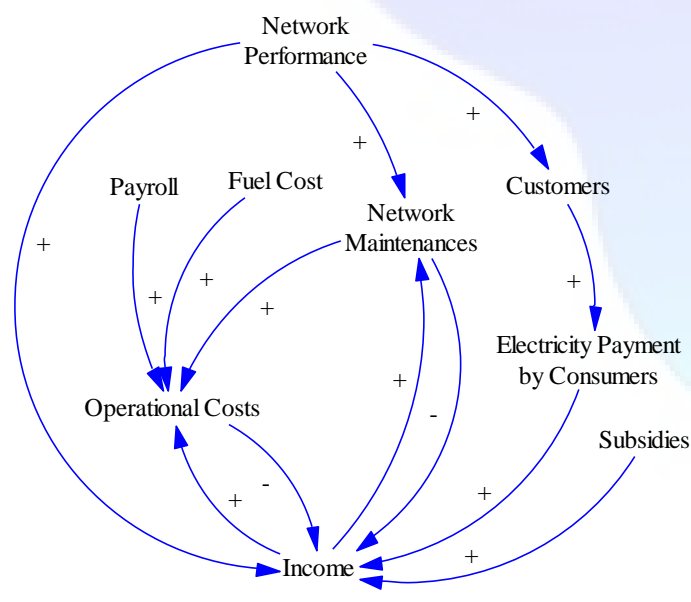

Gambar 4. Keterkaitan kinerja jaringan, pendapatan dan biaya operasional [9]

Semakin mendekati batas usia ekonomisnya, frekuensi kerusakan aset semakin tinggi, seperti terlihat pada Gambar 3. Selain faktor-faktor tersebut, desain usia aset yang ditetapkan oleh produsen juga akan mempengaruhi kinerja jaringan. Pasokan energi listrik dari PLN kepada pelanggan merupakan salah satu sumber pendapatan PLN selain subsidi dari pemerintah.
Pendapatan ini digunakan untuk menutupi biaya operasional (PT. PLN Persero, 2012).

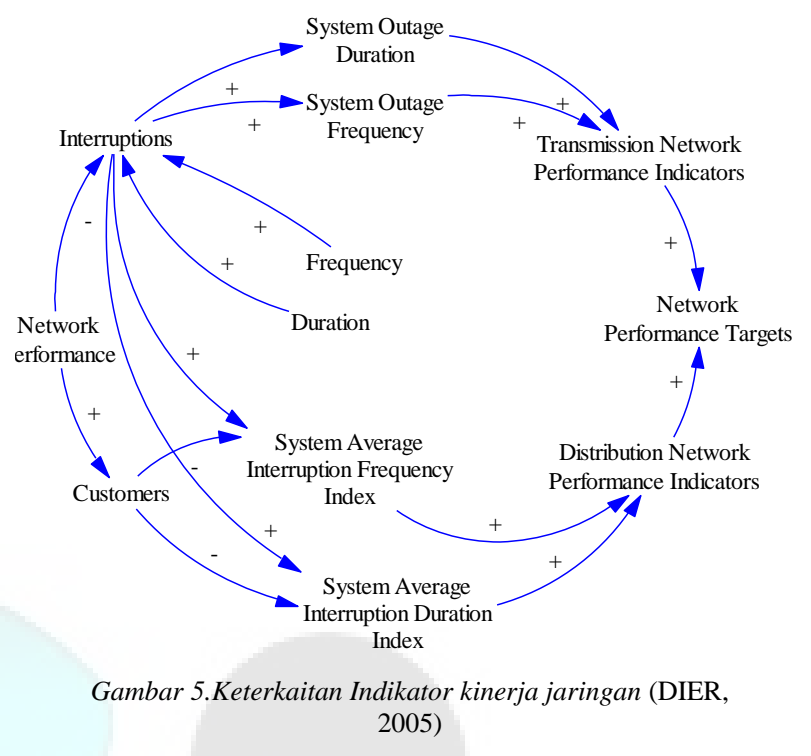

Biaya operasional mencakup biaya bahan bakar, pembelian tenaga listrik dan penyewaan disel, gaji pegawai, dan biaya perawatan, seperti terlihat pada Gambar 4. Indikasi gangguan pada energi listrik dibagi menjadi dua kategori yaitu gangguan transmisi dan distribusi. Indikator gangguan distribusi yang sering dipakai yaitu SAIDI dan SAIFI. Dan dalam hal transmisi yaitu System Outage Duration (SOD) dan System Outage Frequency (SOF) seperti terlihat pada Gambar 5 (PT. PLN Persero, 2012).

Dari beberapa variabel signifikan yang telah dibahas, secara garis besar dapat dilihat bahwa perencanaan pada manajemen aset ditentukan oleh kinerja jaringan dan target kinerja jaringan. Kinerja jaringan dipengaruhi oleh faktor seperti kondisi jaringan, faktor beban, perawatan, dan penggantian aset, temperatur, salinitas, iklim, kondisi geografis. Penentuan target kinerja jaringan didasari oleh kinerja jaringan transmisi dan distribusi, serta manajemen perencanaan aset. Service level dipengaruhi oleh frekuensi dan durasi ganguan (interruption), kinerja jaringan (network performance), serta target kinerja jaringan.

\subsection{Simulasi}

Simulasi dibangun pada beberapa objek PLN seperti aset jaringan tegangan rendah, aset transformer, aset jaringan tegangan menengah. Ketiga aset tersebut akan dilihat kondisi keseluruhan aset, kinerja aset (SAIDI dan SAIFI) dan nilai susut teknisnya. 


\subsubsection{Aset Jaringan Tegangan Rendah}

Simulasi aset jaringan tegangan rendah dikelompokkan sesuai tahun instalasi. Hasil simulasi menunjukkan penurunan rata-rata kondisi aset jaringan tegangan rendah sebesar $1,71 \%$ per tahun. Secara keseluruhan, kondisi aset rata-rata pada jaringan tegangan rendah dengan mempertimbangkan tahun instalasi aset dapat dilihat pada Gambar 6.

\subsubsection{Aset Transformer}

Simulasi aset transformer dikelompokkan sesuai tahun instalasi aset. Hasil simulasi menunjukkan penurunan rata-rata kondisi aset transformer sebesar 2,02\% per tahun. Secara keseluruhan, kondisi aset transformer rata-rata dengan mempertimbangkan tahun instalasi aset dapat dilihat pada Gambar 7. Dari Gambar 7 dapat dilihat bahwa kondisi aset transformer secara umum, sudah berada di bawah acceptable condition, dan memerlukan pembaharuan (untuk periode 1979-1980).

\subsubsection{Aset Jaringan Tegangan Menengah}

Dari hasil running simulasi menunjukkan bahwa rata-rata penurunan aset jaringan tegangan menengah adalah sekitar $1,65 \%$ per tahun. Secara keseluruhan, kondisi aset rata-rata pada jaringan tegangan menengah dengan menimbang tahun instalasi aset ditunjukkan pada Gambar 8.

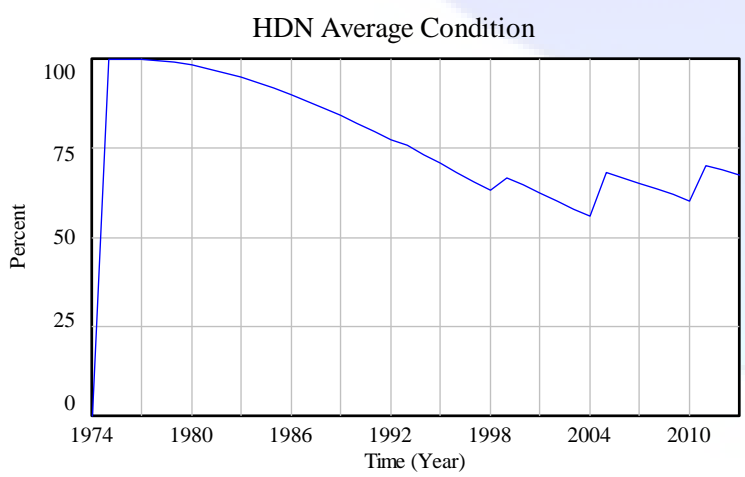

Gambar 6. Kondisi Aset Rata-Rata Pada Jaringan Tegangan Rendah Dengan Mempertimbangkan Tahun Instalasi Aset

Transformer Average Condition

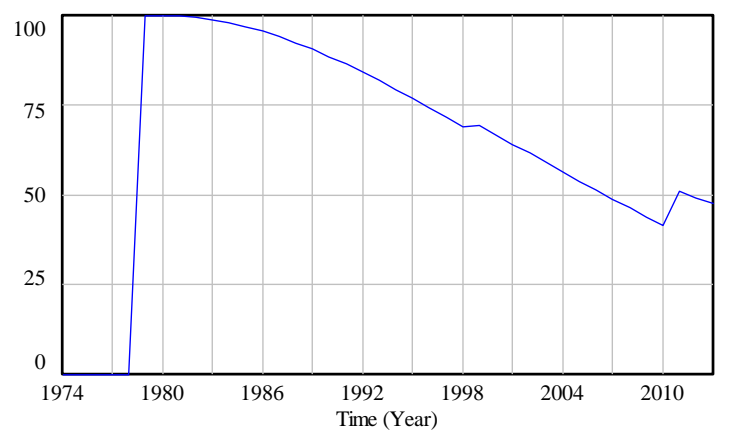

Gambar 7. Kondisi Rata-Rata Transformer dengan Mempertimbangkan Waktu Instalasi

\subsubsection{Rata-rata Kondisi Keseluruhan Aset}

Hasil running terhadap variabel kondisi rata-rata aset dapat dilihat pada Gambar 9. Kondisi ini menggambarkan rata-rata kondisi keseluruhan aset jaringan tegangan rendah, transformer, dan aset jaringan tegangan menengah.

\subsubsection{Kinerja Aset (SAIDI dan SAIFI)}

Indikasi kinerja aset dapat dilihat dari System Average Interruption Duration Index (SAIDI) merupakan rata-rata durasi gangguan pada pelanggan per-tahun dan System Average Interruption Frequency Index (SAIFI) merupakan rata-rata frekuensi gangguan per pelanggan pertahun, semakin tinggi SAIDI dan SAIFI berarti semakin rendah kinerja aset. Dari Gambar 10 dan Gambar 11 dapat dilihat bahwa dalam periode 2005-2013, rata-rata SAIDI $=10,4$ jam/tahun, rata-rata SAIFI = 5,2 kali/pelanggan.

\subsubsection{Susut Teknis}

Susut teknis rata-rata di PLN Pamekasan pada periode 2005-2013 sebesar 18.747.904 KwH/ tahun. Grafik susut teknis dapat dilihat pada Gambar 12.

\subsubsection{Validasi}

Model yang telah dibuat divalidasi dengan melihat perbadingan rata-rata dan perbandingan variasi amplitudo. Dimana model dianggap valid bila $\mathrm{E} 1 \leq 5 \%$ dan $\mathrm{E} 2 \leq 30 \%$. Hasil simulasi variabel susut teknis telah valid $\mathrm{E} 1=3.73 \%$ dan $\mathrm{E} 2=17.31 \%$, maka telah dianggap valid.

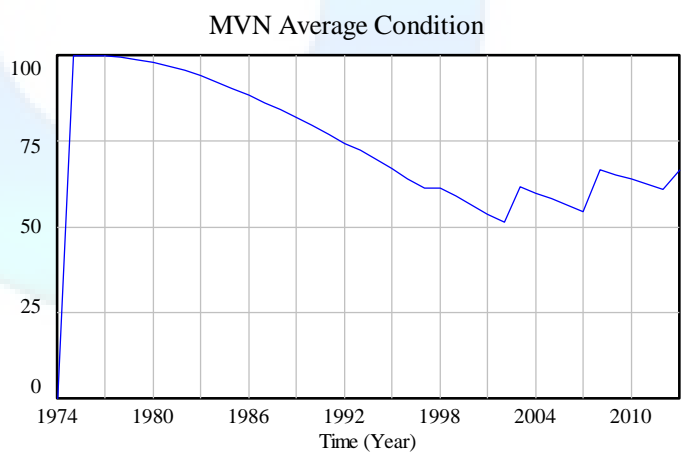

Gambar 8. Kondisi Aset Jaringan Tegangan Menengah Average Asset Condition

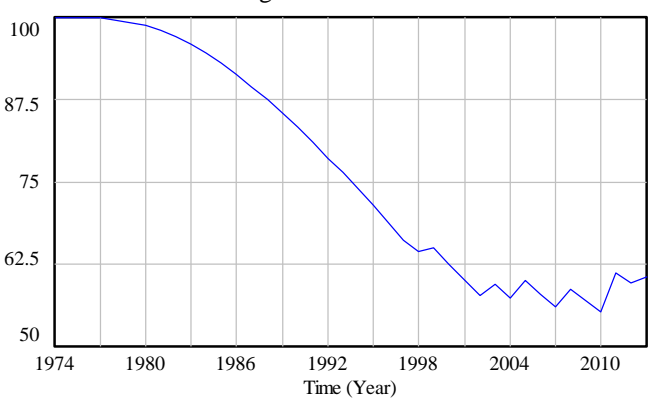

Gambar 9. Kondisi Rata-rata Keseluruhan Aset 


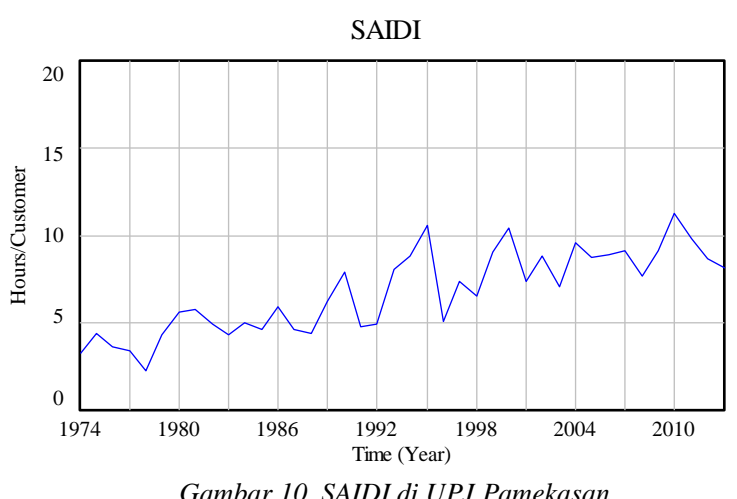

Gambar 10. SAIDI di UPJ Pamekasan

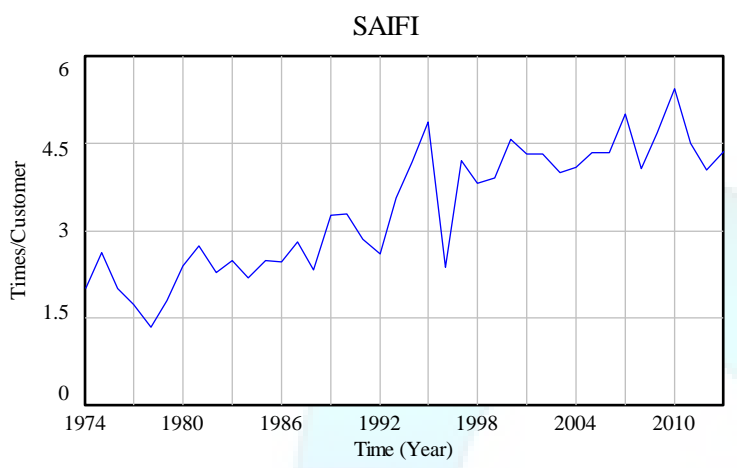

Gambar 11. SAIFI di UPJ Pamekasan

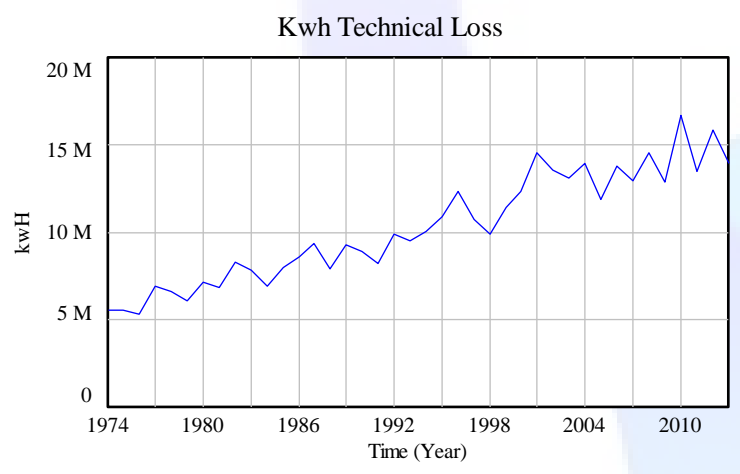

Gambar 12. Susut Teknis Tahunan

\subsection{Skenario}

Model yang telah valid dapat dijadikan rujukan untuk membuat skenario rencana penggantian dan perawatan aset PLN Pamekasan. Skenario dibagi menjadi 3 kategori yaitu: skenario jangka pendek, skenario jangka menengah, dan skenario jangka panjang. Skenario dibuat berdasarkan simulasi kondisi aset saat ini dan penggantian berfokus pada aset yang telah habis masa pakainya yang mana kondisi rata-ratanya dibawah acceptable condition. Skenario jangka pendek meliputi operasional perawatan aset tiap tahun. Pada skenario jangka menengah, difokuskan untuk penggantian aset dengan biaya penggantian rendah seperti kabel saluran rumah. Skenario jangka panjang ini difokuskan untuk penggantian aset dengan biaya penggantian yang tinggi seperti transformer.

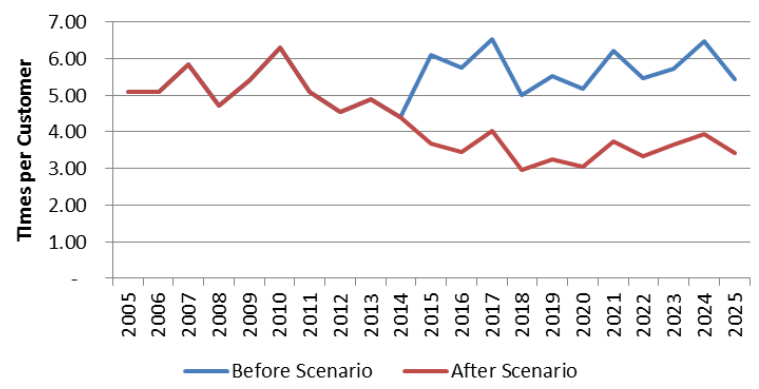

Gambar 13. Grafik simulasi perbandingan SAIFI setelah dilakukan skenario

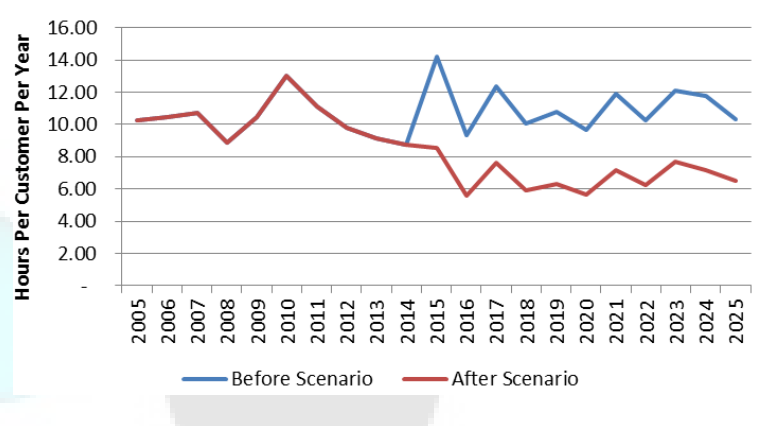

Gambar 14. Grafik simulasi perbandingan SAIDI setelah dilakukan skenario

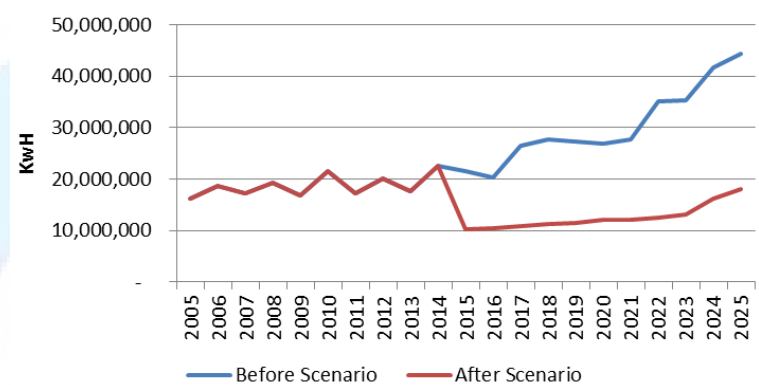

Gambar 15. Grafik simulasi perbandingan susut teknis setelah dilakukan skenario

Simulasi seluruh skenario menunjukkan adanya pengaruh pada penurunan SAIFI hingga 39\% dan penurunan SAIDI hingga 39\%. yang dapat dilihat pada Gambar 13 dan Gambar 14. Simulasi seluruh skenario menunjukkan adanya pengaruh pada pengurangan pada susut teknis $(\mathrm{KwH})$ sekitar 52\%, yang dapat dilihat pada Gambar 15 .

\section{SIMPULAN}

Dari studi yang telah dilakukan, maka dapat disimpulkan beberapa hal sebagai berikut. Secara umum perawatan terhadap aset (maintenance) mempengaruhi kondisi aset dan penurunan kondisi aset (deteriorate) dipengaruhi oleh faktor internal seperti standard lifetime maupun faktor eksternal seperti kondisi geografis, temperatur, kualitas komponen jaringan, faktor beban, iklim, salinitas. 
Berdasarkan hasil eksperimen scenario didapatkan bahwa rata-rata penurunan kondisi aset jaringan tegangan rendah sebesar $1,71 \%$ per tahun. Rata-rata penurunan kondisi aset jaringan tegangan menegah sebesar $2,02 \%$ per tahun. Rata-rata penurunan kondisi transformer sebesar $1,65 \%$ per tahun. Rata-rata kondisi jaringan tegangan rendah dipengaruhi oleh waktu pemasangan aset dalam waktu tertentu dan kondisi aset jaringan pada waktu tertentu tersebut.

Kondisi aset transformer dipengaruhi oleh waktu pemasangan aset dalam waktu tertentu dan kondisi aset jaringan pada waktu tertentu tersebut. Kinerja jaringan dipengaruhi oleh kondisi aset keseluruhan yang berdampak pada susut teknis. Dalam periode 2005-2013, SAIDI rata-rata 10,4 jam/tahun, sedangkan SAIFI ratarata 5,2 kali /pelanggan. Susut teknis pada jaringan disribusi listrik terjadi pada jaringan tegangan menengah, tegangan rendah, sambungan rumah, dan susut transformer.

Susut teknis rata-rata di PLN Pamekasan sebesar 18.747.904 KWH/Tahun. Skenario jangka pendek meliputi operasional perawatan aset tiap tahun. Pada skenario jangka menengah, difokuskan untuk penggantian aset dengan biaya penggantian rendah seperti kabel saluran rumah. Skenario jangka panjang ini difokuskan untuk penggantian aset dengan biaya penggantian yang tinggi seperti transformer. Simulasi pada skenario menunjukkan penurunan SAIFI dan SAIDI hingga $39 \%$, dan penurunan susut teknis $(\mathrm{KwH})$ hingga $52 \%$

\section{DAFTAR RUJUKAN}

Barlas, Y. (1996). Formal aspects of model validity and validation in system dynamics. System Dynamics Review, 12, 183-210.

Crisp, J. J. (2004). Asset Management in Electricity Transmission Enterprises: Factors that affect Asset Management Policies and Practices of Electricity Transmission Enterprises and their Impact on Performance. Brisbane: Queensland University of Technology.

DIER. (2005). Strategic Asset Management Plan. Tasmania: Department of Infrastructure, Energy and Resources.

Gaul, A. J., Spitzer, H., \& Nilges, J. (2004). Strategische Investitionsplanung - Praxisnahe Wege für eine nachhaltige Bewirtschaftung der Assets (Strategic Investment Planning Practical ways for the sustainable management of assets). Energiewirtschaftliche Tagesfragen, 54, 655-656.

OFGEM. (2003). Electricity distribution losses. Office of Gas and Electricity Market - A Consultation Document.

PT. PLN (Persero). (2010). Standar Konstruksi Sambungan Tenaga Listrik. Jakarta: PT PLN (PERSERO).

PT. PLN Persero. (2012). Rencana Usaha Penyediaan Tenaga Listrik 2012-2021. Surabaya.

Richardson. (2013). System Dynamics. Encyclopedia of Operations Research and Management Science. John Wiley And Sons, Inc.

Sterman, J. D. (2000). Business Dynamics: Systems Thinking and Modeling for a Complex World. New York: Jeffrey J. Shelstad.

Top Energy. (2008). Network Loss Factor Methodology. New Zealand: Top Energy Limited.

Wenzler, \& Ivo. (2005). Development of An Asset Management Strategy for A Network Utility Company: Lessons from A Dynamic Business Simulation Approach. SImulation and Gaming, 36, 75-90. 


\section{LAMPIRAN}

Diagram Flow Kinerja Aset

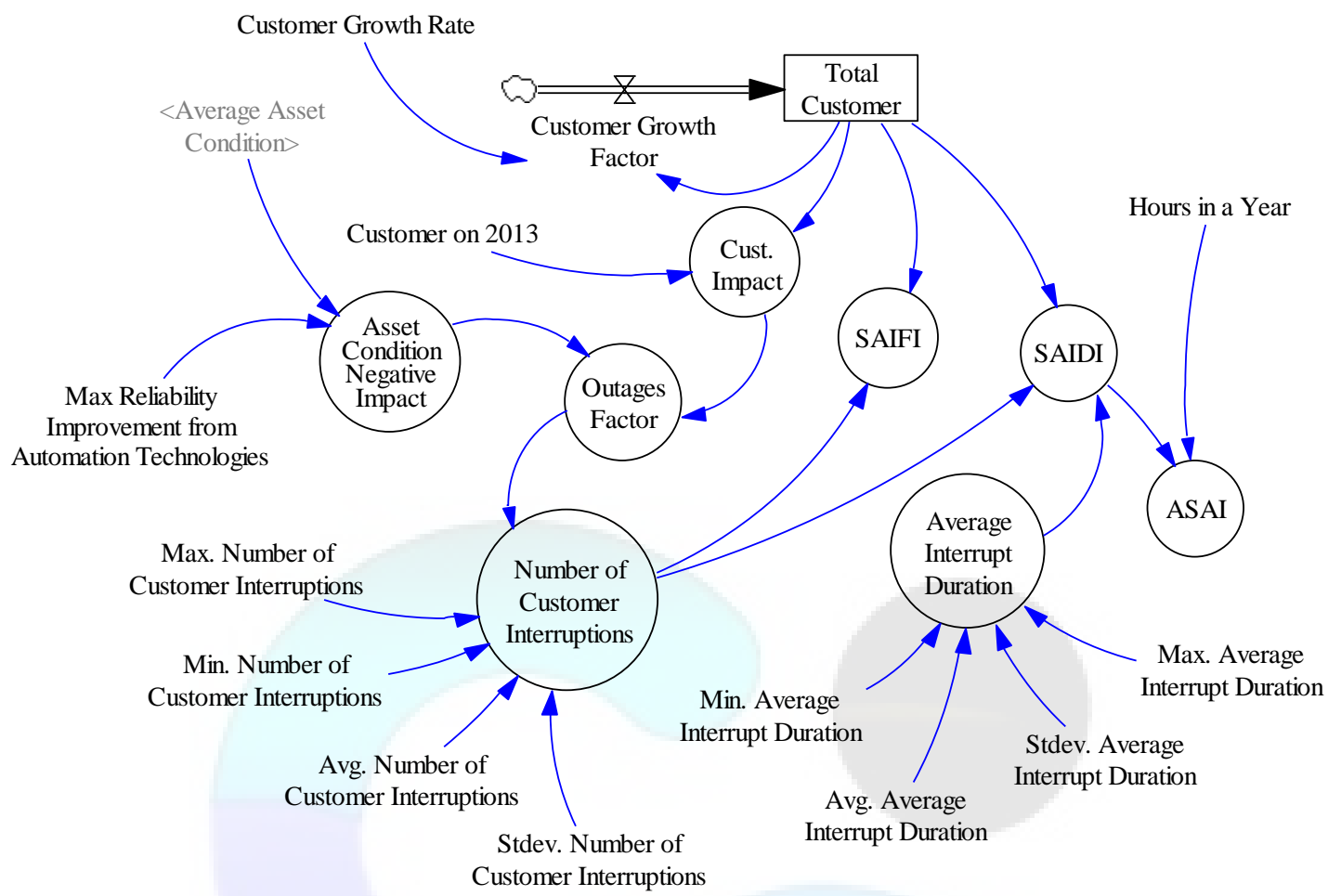

Diagram Flow Susut Teknis

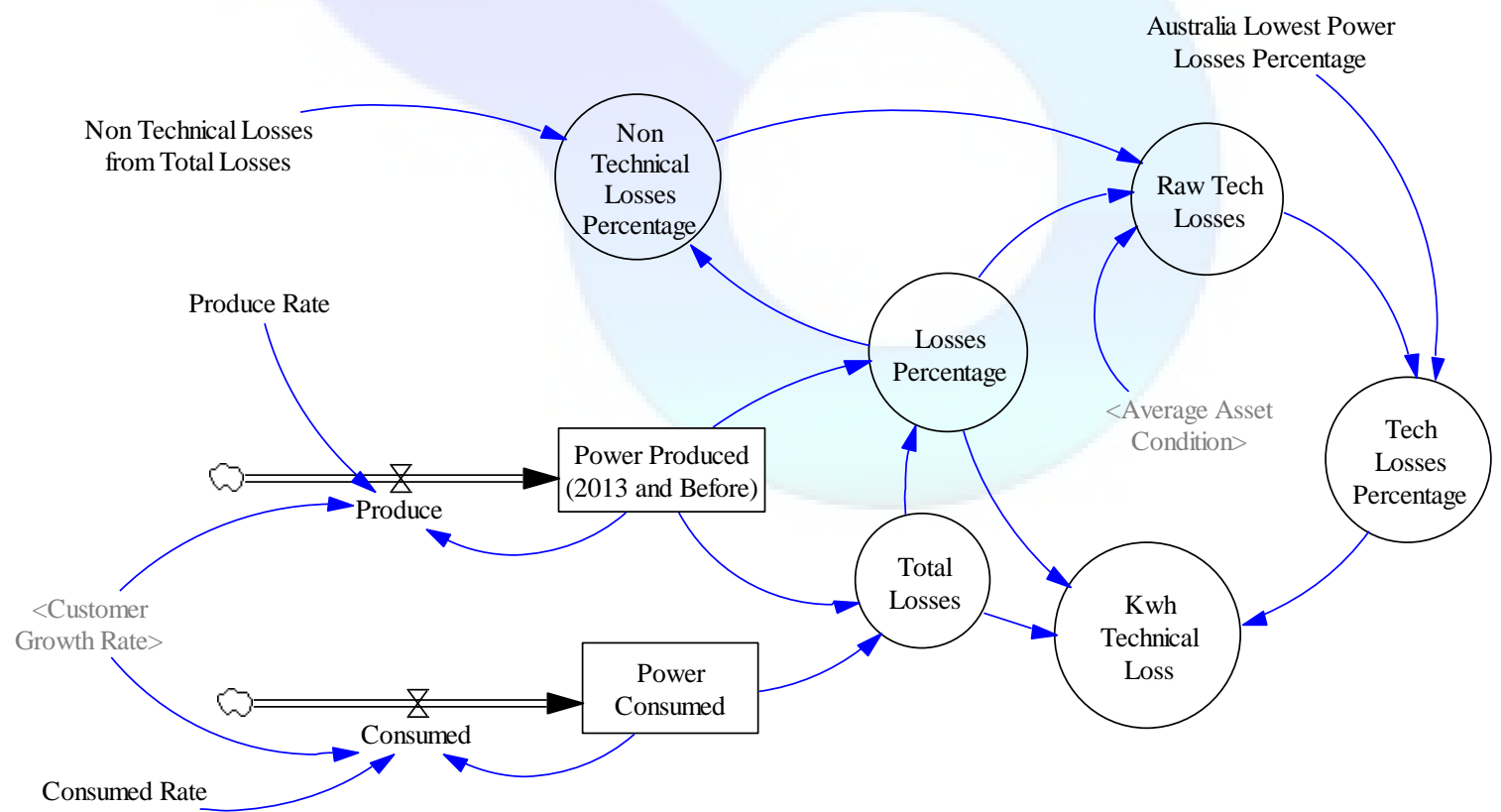


Tabel Perbandingan Sebelum dan Sesudah Skenario

\begin{tabular}{|c|c|c|c|c|c|c|c|c|c|c|c|c|c|c|c|c|}
\hline \multirow[b]{2}{*}{ Year } & \multicolumn{8}{|c|}{ No Changes (No skenario) } & \multicolumn{8}{|c|}{ Skenario All } \\
\hline & 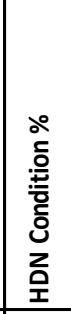 & 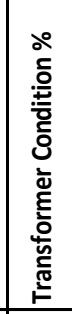 & 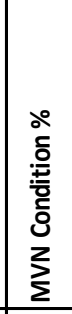 & 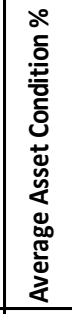 & 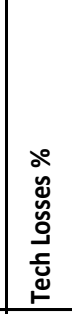 & 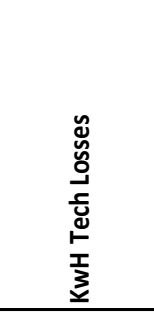 & 荾 & 㖘 & 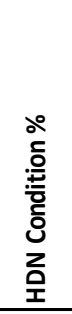 & 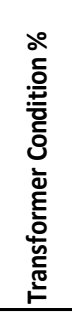 & 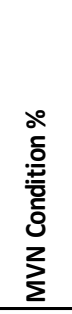 & 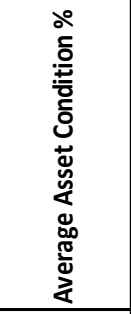 & 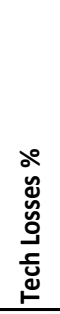 & 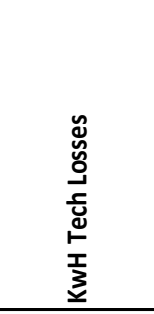 & 㭊 & 高 \\
\hline 2015 & 55,0 & 30,7 & 55,8 & 47,2 & 12,4 & 21.653 .396 & 6,09 & 14,20 & 95,8 & 97,7 & 64,0 & 85,83144 & 5,9 & 10.287 .746 & 3,67 & 8,55 \\
\hline 2016 & 53,2 & 29,3 & 54,1 & 45,5 & 11,3 & 20.311 .482 & 5,76 & 9,35 & 94,9 & 97,4 & 62,5 & 84,94926 & 5,9 & 10.533 .837 & 3,44 & $5,5 \varepsilon$ \\
\hline 2017 & 51,4 & 27,9 & 52,3 & 43,9 & 14,4 & 26.487 .236 & 6,52 & 12,38 & 94,0 & 96,8 & 61,0 & 83,92658 & 5,9 & 10.881 .124 & 4,01 & 7,62 \\
\hline 2018 & 49,5 & 26,6 & 50,3 & 42,1 & 14,6 & 27.636 .694 & 5,00 & 10,03 & 92,8 & 96,1 & 59,4 & 82,77585 & 5,9 & 11.177 .737 & 2,96 & 5,94 \\
\hline 2019 & 47,5 & 25,2 & 48,3 & 40,3 & 14,1 & 27.300 .598 & 5,53 & 10,77 & 91,5 & 95,1 & 57,8 & 81,46316 & 5,9 & 11.428 .144 & 3,25 & 6,33 \\
\hline 2020 & 45,5 & 23,8 & 46,3 & 38,5 & 13,5 & 26.930 .720 & 5,18 & 9,65 & 90,1 & 93,9 & 56,1 & 80,03378 & 6,1 & 12.073 .312 & 3,04 & 5,66 \\
\hline 2021 & 43,4 & 22,5 & 44,1 & 36,7 & 13,6 & 27.812 .520 & 6,21 & 11,93 & 88,5 & 92,5 & 54,4 & 78,47273 & 6,0 & 12.182 .615 & 3,74 & 7,19 \\
\hline 2022 & 41,3 & 21,2 & 42,0 & 34,8 & 16,7 & 35.141 .388 & 5,46 & 10,26 & 86,8 & 91,0 & 52,6 & 76,79627 & 6,0 & 12.513 .098 & 3,32 & 6,23 \\
\hline 2023 & 39,2 & 19,9 & 39,8 & 33,0 & 16,3 & 35.299 .808 & 5,72 & 12,07 & 84,9 & 89,3 & 50,8 & 75,0052 & 6,1 & 13.166 .050 & 3,65 & 7,69 \\
\hline 2024 & 37,1 & 18,7 & 37,6 & 31,1 & 18,8 & 41.606 .276 & 6,48 & 11,78 & 83,0 & 87,4 & 49,0 & 73,11438 & 7,3 & 16.245 .059 & 3,95 & 7,19 \\
\hline 2025 & 35,0 & 17,5 & 35,4 & 29,3 & 19,5 & 44.469 .412 & 5,45 & 10,29 & 80,9 & 85,4 & 47,2 & 71,1513 & 8,0 & 18.148 .952 & 3,43 & $6,4 \varepsilon$ \\
\hline
\end{tabular}

